\title{
The bactericidal activity of gemifloxacin (SB-265805)
}

\author{
I. MORRISSEY, S. CLARK and I. MATHIAS
}

GR Micro Ltd, 7-9 William Road, London NW1 3ER

\begin{abstract}
The bactericidal activity and mechanisms of action of the new fluoroquinolone gemifloxacin were investigated against the laboratory strains Escherichia coli KL16, Staphylococcus aureus E3T and Streptococcus pneumoniae C3LN4. Gemifloxacin was found to be highly bactericidal against these bacteria, producing a biphasic doseresponse curve typical of the fluoroquinolones. This novel fluoroquinolone was more bactericidal than all other fluoroquinolones so far tested (ciprofloxacin, ofloxacin, enoxacin, lomefloxacin, levofloxacin, clinafloxacin, trovafloxacin, DV-7751 and sitafloxacin) against $S$. aureus and was more bactericidal than most other fluoroquinolones against $E$. coli or Str. pneumoniae. These data show gemifloxacin to be an improved member of the fluoroquinolone class of antibacterial agents.
\end{abstract}

\section{Introduction}

The bactericidal activity of numerous fluoroquinolones has been assessed in a series of studies [1]. This bactericidal activity has been characterised into four mechanisms of action ( $\mathrm{A}, \mathrm{B}, \mathrm{C}$ and $\mathrm{B}_{1}$ ) based on experiments investigating kill in phosphate-buffered saline (PBS), i.e., against non-multiplying bacteria, or kill in the presence of chloramphenicol (to prevent protein synthesis). Mechanism A requires bacteria to be multiplying and to be actively undertaking protein and RNA synthesis [2]. This is the basic mechanism of action shared by all quinolones and is the sole mechanism of action of older quinolones such as nalidixic acid. Mechanism $B$ does not require multiplying bacteria or protein and RNA synthesis [2]. Mechanism B is shown by many modern fluoroquinolones against Escherichia coli [1]. However, this does not guarantee that this mechanism of action will be present against other bacteria. For example, ciprofloxacin does not possess mechanism B against Staphylococcus aureus [3], whereas levofloxacin does [4]. Against Streptococcus pneumoniae, only sitafloxacin has been found to possess this additional mechanism [1]. Mechanism $C$, on the other hand, does not require multiplying bacteria but does require active protein and RNA synthesis [1]. This mechanism has been identified

Received 14 Sept. 1999; revised version accepted 10 Feb. 2000.

Corresponding author: Dr I. Morrissey (e-mail: i.morrissey (a)grmicro.co.uk). only with enoxacin [5] and norfloxacin [6]. Mechanism $\mathrm{B}_{1}$ is the most recently discovered mechanism of action. This mechanism does not require protein or RNA synthesis, but is lost against non-dividing bacteria. Mechanism $B_{1}$ has been identified with clinafloxacin against E. coli or staphylococci [7] and with sitafloxacin or trovafloxacin against Enterococcus faecalis $[1,8]$.

This study assessed the bactericidal activity of gemifloxacin (SB-265805), a new (C-73-aminomethyl-4methyimino-1-pyrrolidinyl substituted 1,8-napthyridine) fluoroquinolone. Preliminary studies suggested that gemifloxacin has enhanced antibacterial activity, especially against gram-positive bacteria [9].

\section{Materials and methods}

\section{Antimicrobial agents}

Gemifloxacin was supplied by SmithKline Beecham Pharmaceuticals R\&D (New Frontiers Science Park (South), Third Avenue, Harlow, Essex). Stock solutions of $1 \mathrm{~g} / \mathrm{L}$ were prepared in sterile distilled water. Chloramphenicol (Sigma-Aldrich, Poole, Dorset) was first dissolved in methanol and then dissolved in sterile distilled water. Both antibacterial agents were prepared fresh on each day of experimentation.

\section{Bacterial strains}

The following laboratory strains were used in this study: E. coli KL16; S. aureus E3T; Str. pneumoniae 
C3LN4. These strains were chosen because of their use in earlier studies to determine the bactericidal mechanisms of action of other quinolones. The bacteria were stored at $-70^{\circ} \mathrm{C}$ and subcultured on to Nutrient Broth No. 2 (Unipath, Basingstoke, Hants) solidified with bacteriological agar (Unipath) $1.5 \% \mathrm{w} / \mathrm{v}$ before use. For Str. pneumoniae, agar was supplemented with laked horse blood (Unipath) $5 \% \mathrm{v} / \mathrm{v}$.

\section{Bactericidal tests}

The bactericidal activity of gemifloxacin was investigated by the method of Morrissey and Smith [1]. Briefly, a range of concentrations from 0.005 to $10 \mathrm{mg} / \mathrm{L}$ was prepared in nutrient broth no. 2. Bacteria were inoculated to an initial inoculum size of $c$. $10^{7} \mathrm{cfu} / \mathrm{L}$ and incubated for $3 \mathrm{~h}$ at $37^{\circ} \mathrm{C}$. When Str. pneumoniae was used, the medium was supplemented with laked horse blood to $7 \% \mathrm{v} / \mathrm{v}$. The presence of additional mechanisms ( $\mathrm{B}, \mathrm{B}_{1}$ or $\mathrm{C}$ ) was assessed by the addition of chloramphenicol $20 \mathrm{mg} / \mathrm{L}(2.5 \mathrm{mg} / \mathrm{L}$ for Str. pneumoniae) to prevent protein synthesis or by replacing nutrient broth with PBS to prevent bacterial multiplication. To prevent autolysis of Str. pneumoniae, horse serum (Unipath) at $7 \% \mathrm{v} / \mathrm{v}$ was added when this organism was studied in PBS. After incubation, 1-ml samples were taken, centrifuged and resuspended in an equal volume of sterile nutrient broth no. 2. This washing step was repeated twice to prevent drug carryover. Viable counts of these samples were made on solid agar by spiral plating and the plates were incubated for $48 \mathrm{~h}$ at $35^{\circ} \mathrm{C}$. Percentage survival was calculated and plotted against drug concentration tested.

\section{Results}

Gemifloxacin produced a biphasic dose-response against $E$. coli KL16, S. aureus E3T and Str. pneumoniae $\mathrm{C} 3 \mathrm{LN} 4$, producing an optimum bactericidal concentration for gemifloxacin against each test strain: E. coli KL16 $1 \mathrm{mg} / \mathrm{L}, S$. aureus E3T $0.5 \mathrm{mg} / \mathrm{L}$ and Str. pneumoniae C3LN4 $0.5 \mathrm{mg} / \mathrm{L}$ (Fig. 1a,b,c). This phenomenon is typical of the fluoroquinolones [2].

The addition of a bacteriostatic concentration of chloramphenicol reduced the bactericidal activity of gemifloxacin against E. coli (Fig. 1a). However, some bactericidal activity still occurred in the presence of this inhibitor of protein synthesis. On the other hand, when the activity of gemifloxacin was tested in PBS, considerably less bactericidal activity was observed against E. coli (Fig. 1a). Therefore, it appears that gemifloxacin could kill bacteria devoid of protein synthesis but was less able to kill fully non-multiplying bacteria incubated in PBS. Therefore, gemifloxacin possesses bactericidal mechanisms $\mathrm{A}$ and $\mathrm{B}_{1}$ against $E$. coli.

Slightly stronger bactericidal activity occurred against $S$. aureus in nutrient broth than that seen against $E$. coli (Fig. 1b). Reduced killing of the staphylococcus was seen when chloramphenicol was added or when experiments were performed in PBS (Fig. 1b). Nevertheless, good bactericidal activity still occurred against $S$. aureus E3T under these conditions, i.e., against staphylococci unable to undergo protein synthesis or against staphylococci unable to multiply. Therefore, it is evident that gemifloxacin possesses bactericidal mechanisms A and B against S. aureus.
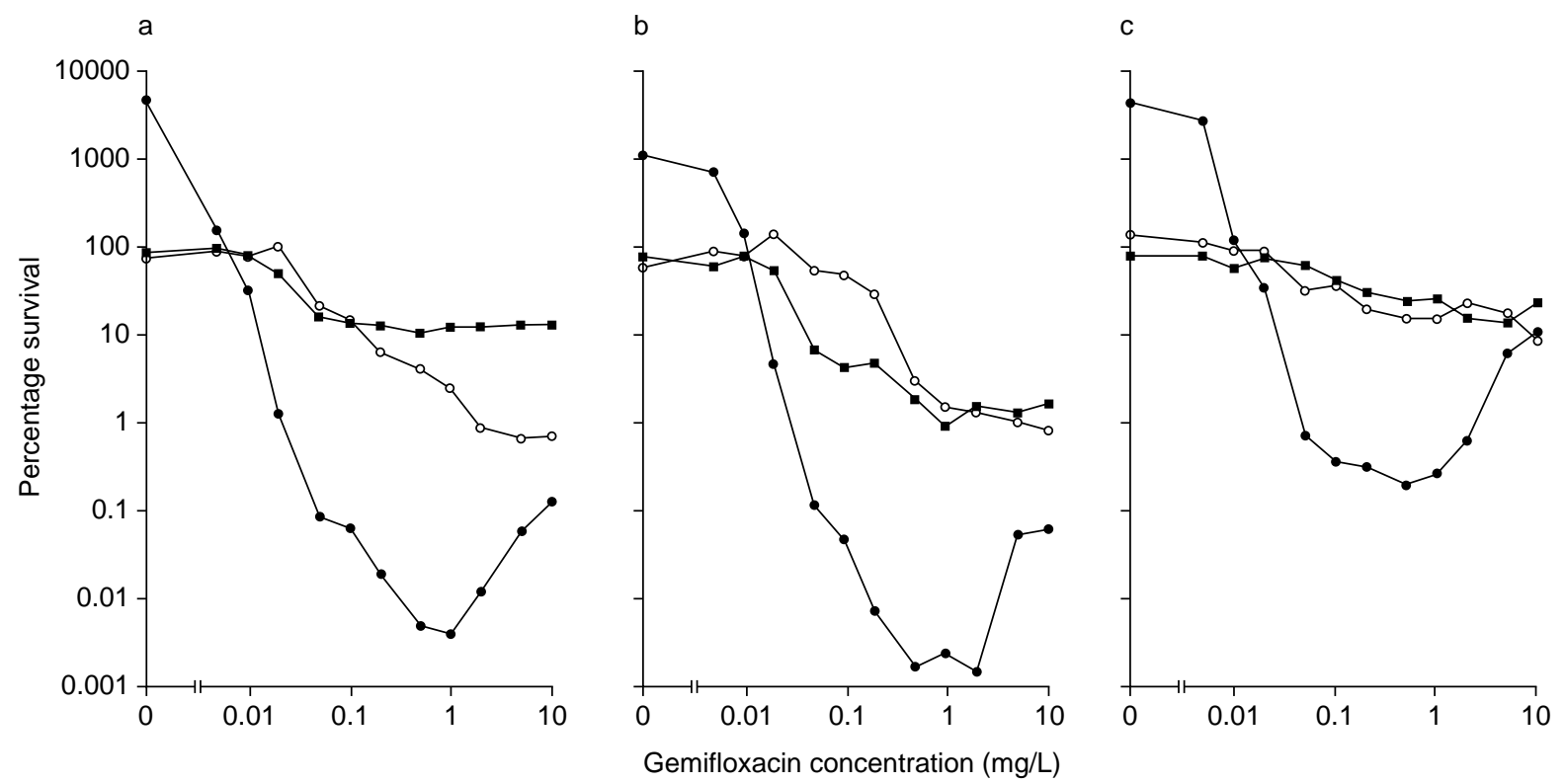

Fig. 1. Survival of (a) E. coli KL16, (b) S. aureus E3T and (c) Str. pneumoniae C3LN4 treated with gemifloxacin for $3 \mathrm{~h}$ at $37^{\circ} \mathrm{C}$ : $\bullet$, nutrient broth $(\mathbf{a}, \mathbf{b})$ or blood broth (c; nutrient broth with laked horse blood $\left.7 \%\right)$; 0 , nutrient broth $(\mathbf{a}, \mathbf{b})$ or blood broth (c) plus chloramphenicol $20 \mathrm{mg} / \mathrm{L}$; a, PBS (a,b) or PBS with horse serum $7 \%$ (c). 
Table 1. Comparison of bactericidal activity of gemifloxacin, trovafloxacin and sitafloxacin

\begin{tabular}{|c|c|c|c|c|c|c|}
\hline \multirow[b]{2}{*}{ Test strain } & \multirow[b]{2}{*}{ Quinolone } & \multirow[b]{2}{*}{$\mathrm{OBC}(\mathrm{mg} / \mathrm{L})$} & \multicolumn{3}{|c|}{ Percentage survival in } & \multirow[b]{2}{*}{ Reference no. } \\
\hline & & & NB & $\mathrm{NB}+\mathrm{Cm}$ & PBS & \\
\hline $\begin{array}{l}\text { E. coli } \\
\text { KL16 }\end{array}$ & $\begin{array}{l}\text { Gemifloxacin } \\
\text { Trovafloxacin } \\
\text { Sitafloxacin }\end{array}$ & $\begin{array}{l}1.0 \\
1.5 \\
0.9\end{array}$ & $\begin{array}{l}0.004 \\
0.009 \\
0.0005\end{array}$ & $\begin{array}{l}2.5 \\
1.9 \\
0.028\end{array}$ & $\begin{array}{l}12.3 \\
1.4 \\
0.07\end{array}$ & $\begin{array}{l}\text { This study } \\
{[8]} \\
{[1]}\end{array}$ \\
\hline $\begin{array}{l}\text { S. aureus } \\
\text { E3T }\end{array}$ & $\begin{array}{l}\text { Gemifloxacin } \\
\text { Trovafloxacin } \\
\text { Sitafloxacin }\end{array}$ & $\begin{array}{l}0.5 \\
3.0 \\
3.0\end{array}$ & $\begin{array}{l}0.0017 \\
0.005 \\
0.004\end{array}$ & $\begin{array}{l}3.00 \\
0.16 \\
0.09\end{array}$ & $\begin{array}{l}1.84 \\
0.44 \\
0.18\end{array}$ & $\begin{array}{l}\text { This study } \\
{[8]} \\
{[1]}\end{array}$ \\
\hline $\begin{array}{l}\text { Str. pneumoniae } \\
\text { C3LN4 }\end{array}$ & $\begin{array}{l}\text { Gemifloxacin } \\
\text { Trovafloxacin } \\
\text { Sitafloxacin }\end{array}$ & $\begin{array}{l}0.5 \\
1.5 \\
0.9\end{array}$ & $\begin{array}{l}0.21 \\
0.24 \\
0.10\end{array}$ & $\begin{array}{r}16.2 \\
24.8 \\
0.14\end{array}$ & $\begin{array}{c}25.7 \\
57.5 \\
0.41\end{array}$ & $\begin{array}{l}\text { This study } \\
{[8]} \\
{[1]}\end{array}$ \\
\hline
\end{tabular}

OBC, optimum bactericidal concentration; $\mathrm{NB}$, nutrient broth; $\mathrm{Cm}$, chloramphenicol.

It can be seen from Fig. 1c, that, as with the other two bacterial species tested, gemifloxacin was bactericidal against Str. pneumoniae in nutrient broth (supplemented with laked horse blood). This bactericidal activity was lower than that observed against either E. coli or $S$. aureus. Furthermore, little or no bactericidal activity occurred with gemifloxacin when chloramphenicol was added or when experiments were performed in PBS supplemented with horse serum. Therefore, against the pneumococcus, gemifloxacin did not possess any bactericidal mechanisms other than mechanism A.

\section{Discussion}

The results of this study show that gemifloxacin was bactericidal against E. coli KL16, S. aureus E3T and Str. pneumoniae C3LN4. This new fluoroquinolone possesses additional bactericidal mechanisms of action $\mathrm{B}_{1}$ and B against E. coli KL16 and S. aureus E3T, respectively. However, no such additional mechanisms are present against Str. pneumoniae C3LN4.

For comparative purposes, the results of this study have been presented with the equivalent results obtained previously with trovafloxacin and sitafloxacin (Table 1). It can be seen that gemifloxacin has an optimum bactericidal concentration (OBC) similar to that of sitafloxacin and lower than that of trovafloxacin against E. coli. Gemifloxacin also has the lowest $\mathrm{OBC}$ against Str. pneumoniae. However, most significantly, gemifloxacin has a considerably lower OBC than trovafloxacin or sitafloxacin against $S$. aureus. Furthermore, the bactericidal activity of gemifloxacin at the OBC against $S$. aureus in nutrient broth was also greater than that found with the other fluoroquinolones (Table 1). These results show gemifloxacin to be the most potent fluoroquinolone so far tested against $S$. aureus E3T with this system.

However, it is interesting that the bactericidal advantage of gemifloxacin against $S$. aureus was not retained when chloramphenicol was added or when experiments were performed in PBS (Table 1). In other words, bactericidal mechanism $\mathrm{B}$ with gemifloxacin was not as potent as that seen with trovafloxacin or sitafloxacin.

As seen with trovafloxacin (Table 1), gemifloxacin did not possess bactericidal activity in the presence of chloramphenicol or in PBS against Str. pneumoniae. In fact, sitafloxacin is the only fluoroquinolone known to possess bactericidal activity against Str. pneumoniae C3LN4 under these experimental conditions [1].

It is important to note that the strains used in this study are laboratory control strains - originally part of the culture collection at the School of Pharmacy, University of London. These strains were used for continuity and for comparison with previous investigations on the bactericidal mechanisms of action of quinolones. A similar but larger study of recent clinical isolates would be useful and may clarify the clinical significance of this and previous bactericidal investigations.

In conclusion, gemifloxacin showed reduced bactericidal activity when bacteria were unable to multiply due to weak additional mechanisms $\mathrm{B}$ or $\mathrm{B}_{1}$ compared with trovafloxacin or sitafloxacin. Nevertheless, gemifloxacin showed very strong bactericidal activity against multiplying bacteria, especially against $S$. aureus E3T, compared with sitafloxacin and trovafloxacin. The clinical significance of these differences may become clear after further evaluation of gemifloxacin.

\section{References}

1. Morrissey I, Smith JT. Bactericidal activity of the new 4quinolones DU-6859a and DV-7751a. J Med Microbiol 1995; 43: 4-8.

2. Lewin CS, Morrissey I, Smith JT. The mode of action of quinolones: the paradox in activity of low and high concentrations and activity in the anaerobic environment. Eur J Clin Microbiol Infect Dis 1991; 10: 240-248.

3. Lewin CS, Smith JT. Bactericidal mechanisms of ofloxacin. $J$ Antimicrob Chemother 1988; 22 Suppl C: 1-8.

4. Lewin CS, Amyes SGB. The bactericidal activity of DR-3355, an optically active isomer of ofloxacin. J Med Microbiol 1989; 30: 227-231.

5. Lewin CS, Amyes SGB, Smith JT. Bactericidal activity of 
enoxacin and lomefloxacin against Escherichia coli KL16. Eur $J$ Clin Microbiol Infect Dis 1989; 8: 731-733.

6. Ratcliffe NT, Smith JT. Norfloxacin has a novel bactericidal mechanism unrelated to that of other 4-quinolones. J Pharm Pharmacol 1985; 37 Suppl: 92P.

7. Lewin CS, Amyes SGB. Bactericidal action of PD127,391, an enhanced spectrum quinolone. J Med Microbiol 1990; 33: 67-70.
8. Morrissey I. Bactericidal activity of trovafloxacin (CP-99,219). $J$ Antimicrob Chemother 1996; 38: 1061-1066.

9. Paek K-S, Kim M-Y, Choo YS. SB-265805 (LB20304a): in vitro antibacterial activity and spectrum. Abstracts of the 38th Interscience Conference on Antimicrobial Agents and Chemotherapy. Washington, DC, American Society for Microbiology. 1998. Abstract F-92: 255. 